\title{
Retraction Note to: The Ogallala Formation of the Great Plains in Central US and Its Containment of Life-Giving Water
}

\author{
Marios Sophocleous ${ }^{1,3}$ and Dan Merriam²
}

\section{Retraction Note to: Natural Resources \\ Research 21(4), 2012, 415-426 \\ DOI 10.1007/s11053-012-9190-4}

The afore mentioned article, published online: 26 October 2012 on SpringerLink (www.link. springer.com), has been retracted by agreement between the authors' sponsoring institution, the journal's Editor-in-Chief, the IAMG publications committee and Springer. The retraction has been agreed upon following investigations by the Kansas Geological Survey (a research and service division of the University of Kansas), the IAMG publications committee, the Editor-in-Chief and Springer, which identified unattributed areas of overlap with a number of other publications.

${ }^{1}$ Kansas Geological Survey, University of Kansas, Lawrence KS 66047, USA.

${ }^{2}$ University of Kansas, Campus West, 1930 Constant Avenue, Lawrence KS 66047, USA.

${ }^{3}$ To whom correspondence should be addressed; e-mail: marios@kgs.ku.edu

The online version of the original article can be found under doi: 10.1007/s11053-012-9190-4. 